\title{
Origin and Distribution of Carbonate Cement in Tight Sandstones: The Upper Triassic Yanchang Formation Chang 8 Oil Layer in West Ordos Basin, China
}

\author{
Jin Lai, ${ }^{1,2}$ Guiwen Wang, ${ }^{1,2}$ Jing Chen, ${ }^{1}$ Shuchen Wang, ${ }^{1}$ \\ Zhenglong Zhou, ${ }^{1}$ and Xuqiang Fan ${ }^{1}$ \\ ${ }^{1}$ College of Geosciences, China University of Petroleum, Beijing 102249, China \\ ${ }^{2}$ State Key Laboratory of Petroleum Resources and Prospecting, China University of Petroleum, Beijing 102249, China
}

Correspondence should be addressed to Jin Lai; sisylaijin@163.com

Received 13 February 2017; Revised 25 April 2017; Accepted 14 June 2017; Published 30 July 2017

Academic Editor: Xiaorong Luo

Copyright ( 2017 Jin Lai et al. This is an open access article distributed under the Creative Commons Attribution License, which permits unrestricted use, distribution, and reproduction in any medium, provided the original work is properly cited.

Two generations of carbonate cement as Type I (microcrystalline calcite and dolomite) and Type II (mainly Fe-calcite and Fedolomite) are recognized in Chang 8 sandstones, Ordos basin. Carbonate cement in Chang 8 sandstones is closely related to the dissolved carbon from thermal maturation of organic matters. Carbonate cement in the loosely packed framework grains precipitated shortly after deposition, and late-stage ferroan calcite and ferroan dolomite formed with progressive burial. The early diagenetic carbonate cement is partially to completely replaced by late-stage ferroan calcite and ferroan dolomite. Carbonate cement is much more commonly observed in sand bodies adjacent to Chang 7 source rocks. With increasing distance from the Chang 7 oil layers, the carbonate cement content gradually decreases. However, some tight carbonate cemented zones also occur at the sandstone-mudstone interfaces. Dissolution of Ca-feldspars by organic acids-rich fluids, together with clay mineral transformations such as illitization of smectite, would provide $\mathrm{Ca}^{2+}$ and $\mathrm{Mg}^{2+}$ ions for carbonate cementation. Organic acids and $\mathrm{CO}_{2}$ rich fluids would charge into the reservoirs with the hydrocarbons, and when the $\mathrm{CO}_{2}$ and acids were buffered by the framework grain dissolution, carbonate cement would precipitate with a decrease in $\mathrm{CO}_{2}$ concentration.

\section{Introduction}

The Ordos basin is the second largest petroliferous sedimentary basin in China $[1,2]$. The basin was part of the North China Craton prior to the Paleozoic, and it became an isolated lake basin during the Middle and Late Triassic [3]. A series of lacustrine and deltaic clastic sediments, which were known as the Yanchang Formation, were deposited during this time [3]. The Upper Triassic Yanchang Formation, which is underlain by the Middle Zhifang Formation and overlain by the Lower Jurassic Yanan Formation (Figure 1; [4]), is a significant oil-producing bed in the Ordos basin $[3,5]$. The Chang 8 (eighth member of Yanchang Formation) sandstones, which consist of braided-delta subaqueous distributary channels, are important reservoir units [4]. However, the Chang 8 sandstones, which had experienced various types and degrees of diagenesis such as compaction and cementation by carbonates and clays, are typical tight reservoirs with low porosity, low permeability, and strong microscopic heterogeneity (Zeng and Li 2009; [4, 6, 7]).

Understanding diagenetic heterogeneity is vital for hydrocarbon exploration in tight sandstone reservoirs [8]. Carbonate cementation is an important diagenetic alteration that has profound impact on sandstone reservoir quality and heterogeneity [9-12]. Precipitation of carbonate cement is an important agent of lithification [11], and it often contributes to the poor reservoir property. When the carbonate cement fills the pore space completely, the reservoir quality will become so poor that they may act as baffles or seepage barriers to fluid flow $[13,14]$. The carbonate cementation in sedimentary rocks may be spatially discontinuous, producing conspicuous structures called concretions [11].

Carbonate cement is the predominant diagenetic minerals in Chang 8 sandstones [6]. Mineralogical, petrographic, 


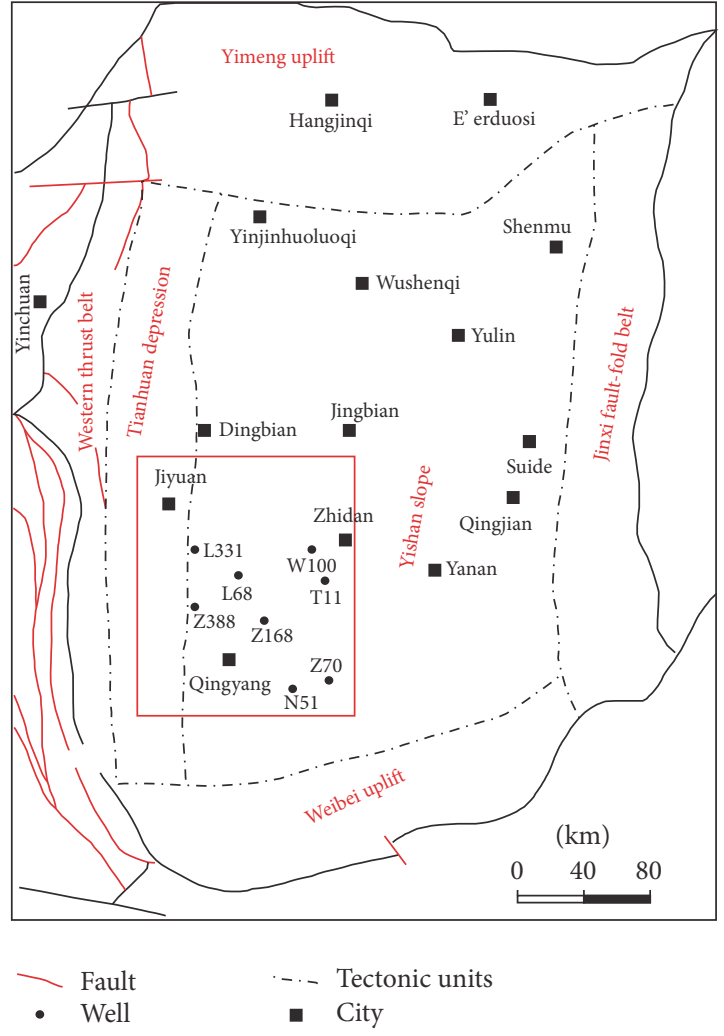

(a)

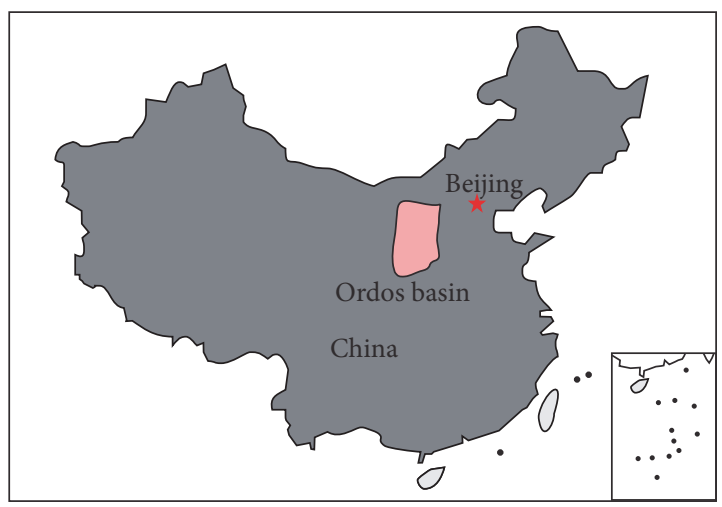

(c)
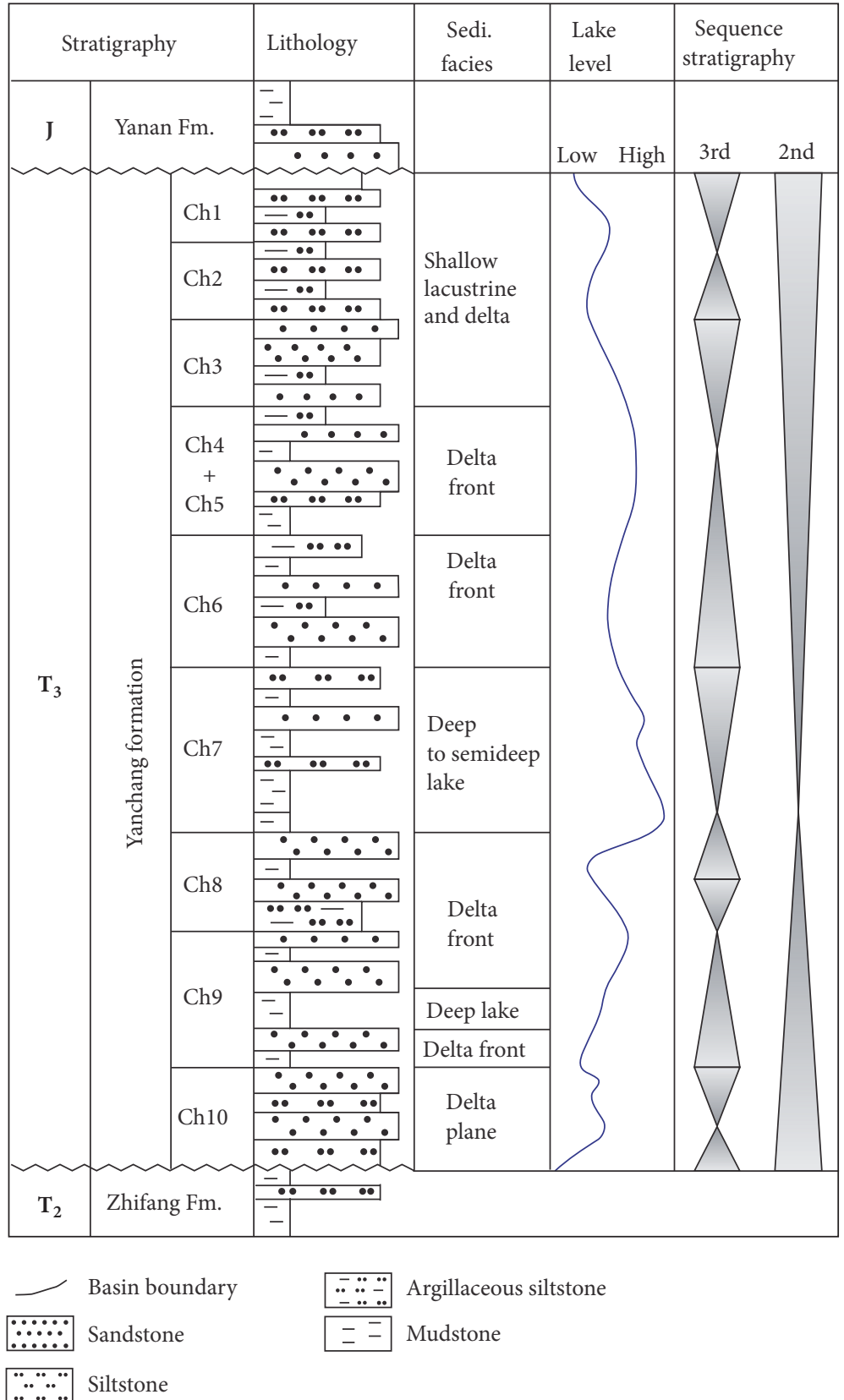

$\ddot{\because \because: \because * . *}$ Argillaceous siltstone z- Mudstone

(b)

Figure 1: (a) The tectonic divisions of Ordos basin (after $[6,18,24,25])$; (b) sequence stratigraphic column of Upper Triassic Yanchang Formation in Ordos basin, $\mathrm{Ch}=$ Chang (after [4]); and (c) map showing the location of the Ordos basin within China.

and geochemical analyses combined with ECS log data were used to describe the petrography and geochemistry of the carbonate cement and associated features in Chang 8 sandstones, with the special aim to unravel the origins, paragenesis, and distribution patterns of carbonate cement. This multidisciplinary work would provide insights into distribution patterns of carbonate cement within a siliciclastic succession and will have scientific significance in similar sandstone successions worldwide.

\section{Geologic Setting}

The Ordos basin is located in the western part of the North China block $[1,3,15]$ and across five provinces: Shaanxi, Gansu, Ningxia, Inner Mongolia, and Shanxi (Figure 1(a); [16]). A series of Cenozoic rift basins separate the Ordos basin from adjoining mountains [17]. The Ordos basin can be divided into six structural units: the Yimeng uplift zone in the north, the Weibei uplift zone in the south, the Jinxi flexural 


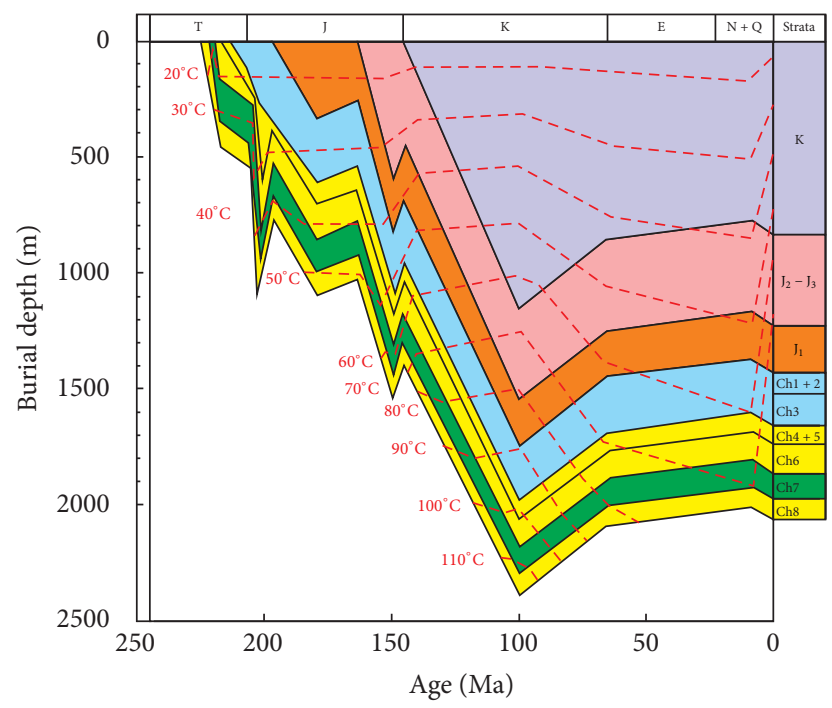

Figure 2: Burial and thermal histories of the Upper Triassic Yanchang Formation for Well L47 in Ordos basin (after [26]).

fold zone in the east, the Yishan slope in the midsection, the Xiyuan obduction zone, and the Tianhuan depression in the west (Figure 1(a); [16, 18-23]). The study area of this paper is located in the west Ordos basin (mainly the Yishan Slope and Tianhuan Depression), and abundant hydrocarbons are produced from the oil fields located in this area, including the Jiyuan, Heshui, Wu 464, Zhengning, and Huachi oil fields (Figure 1). Burial history reconstructions were based on the work of Shi et al., 2012 (Figure 2), and from Figure 2 it can be concluded that the Yanchang Formation had its maximum burial depth at about $100 \mathrm{Ma}$, then followed by an uplift and erosion of 400-500 m of sedimentary strata.

The Ordos basin is a gently dipping, very stable intracratonic basin [32]. The surrounding Yinshan and Qinling Mountains were thought to be the primary provenances for the Upper Triassic fluvial-deltaic sequences [17]. From the aspect of exploration and exploitation purposes, the Yanchang Formation could be subdivided into 10 informal oil reservoir units named Chang 10 to Chang 1 from the bottom to the top based on marker beds, lithological association, and sedimentary cycles, and these oil reservoir units are in conformity contact with each other $[4,17,19,33,34]$. Among them, the Chang 7 oil layers were deposited in a deep lacustrine environment $[5,35,36]$, and the Chang 7 oil layers are good to very good source rocks $[2,37]$. Sections from Chang 10 to Chang 8 represent a transgression sequence deposited at shallow water level, whereas those from Chang 6 to Chang 2 are regression sequences deposited at lake fading stage [5], and Chang 1 oil layer was deposited during the peneplain period [17]. The lithology of Chang 8 sandstones is mainly composed of grey fine to medium-grained sandstones and siltstones interbedded with dark mudstones [6]. Parallel bedding and wedge-shaped cross bedding can be observed in the fineto medium-grained sandstones, and these clean sandstones are formed in a relatively high water energy environment, for example, the underwater distributary channel and mouth bar of a delta front $[27,28,38]$. The siltstones with parallel bedding are mainly deposited in the distal bar microfacies. In contrast, the horizontal bedding can be observed in the dark mudstones, representing a low water energy environment [6].

\section{Samples and Methods}

Core samples and related thin sections were collected from more than 120 wells in the oilfield in the west Ordos basin. Standard modern wire-line logs comprise gamma-ray (GR), spontaneous potential (SP), bulk density (DEN), compensated neutron (CNL), borehole-compensated sonic (AC), and resistivity logs (RT and Rxo). The core-to-log depth matching is done by correlating the GR signature with the core description. ECS logging data is available in some wells such as An 157, Cheng 96, Yue 37, Hao 22, Zheng 53, Ban 28, and Xi 236.

The geochemical ECS logging tool uses a standard americium beryllium (AmBe) neutron source and bismuth germinate (BGO) detector to measure the released gamma rays [39]. By processing the measured $\gamma$-ray energy spectra using an oxide closure method, the ECS can provide information on the mineralogy including the mass fractions of certain components of carbonates, total clay, Q-F-M (quartz, feldspar, and mica), siderite, and pyrite, as well as anhydrite, salt, and coal $[39,40]$. Compared with the standard set of logging data, the high vertical resolution (1.5 ft), open-hole ECS well logs can provide insight into predicting the distribution of carbonates in wells that lack core control.

Core samples and some cutting samples representative of noncored intervals were collected. Diagenesis and petrophysical properties were interpreted from petrographic data and core analyses. A total of 1735 samples analyses of Heporosity and air permeability were obtained. However, there are only 242 samples with their lithology known, and these 242 samples have also measured the carbonate content.

Cathode Luminescence (CL) analyses were performed on polished thin sections to characterize different cement generations using a Technosyn cold cathode luminoscope.

Representative thin sections examined with a petrographic microscope were point counted (300 points per sample) to calculate the relative amounts of detrital framework grains, matrix, authigenic cement, interstitial minerals, and porosity. To examine the volume and distribution of porosity, the thin sections were impregnated with red-dye resin. To distinguish the mineralogy of carbonate cement, they were stained with Alizarin Red $S$ and potassium ferricyanide for identification of ferroan dolomites, ferroan calcites, and nonferroan calcites in thin sections.

\section{Results}

4.1. Reservoir Characteristics. The Chang 8 sandstones are classified as lithic arkose, feldspathic litharenites, and litharenites according to Folk (1980) [6]. Detrital mineralogy is dominated by quartz (mostly monocrystalline), and the dominant feldspars are Ca-feldspars and Na-feldspars. The main types of rock fragments consist mainly of metamorphic rock fragments and volcanic rock fragments (Lai et al., 2014a; [6]). 


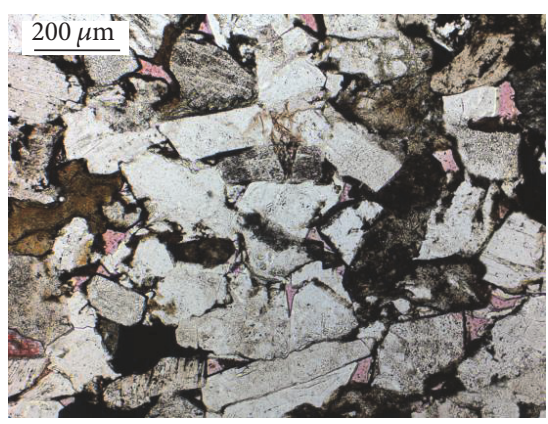

(a)

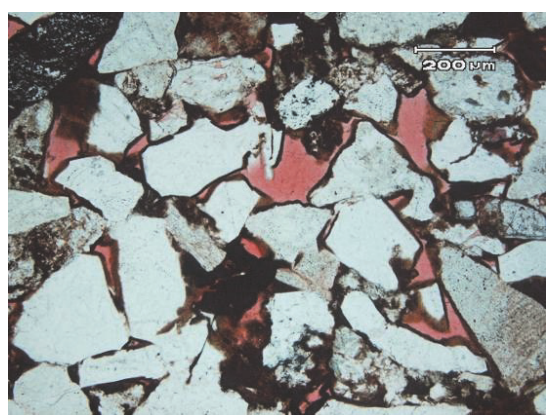

(d)

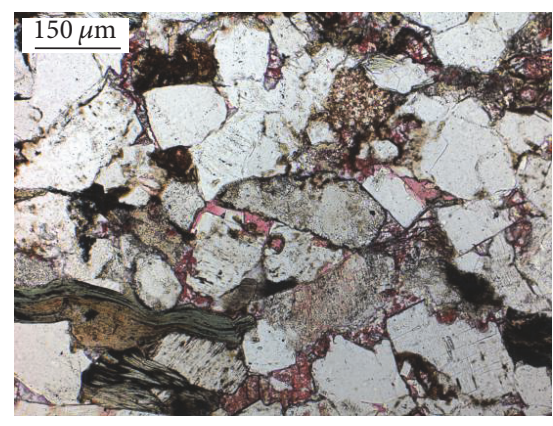

(b)

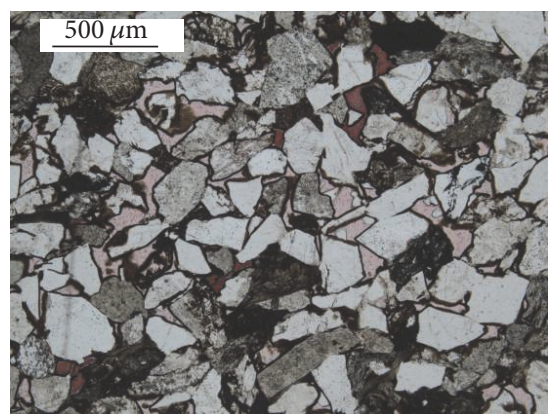

(e)

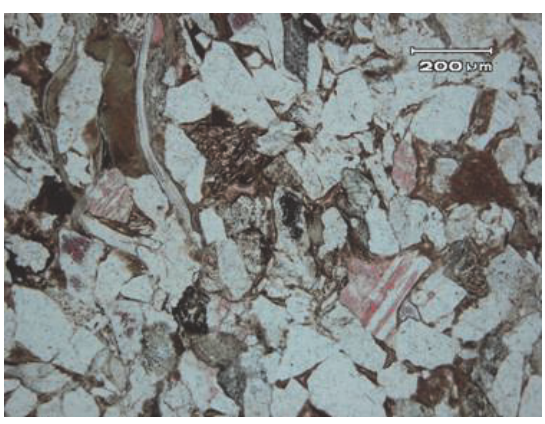

(c)

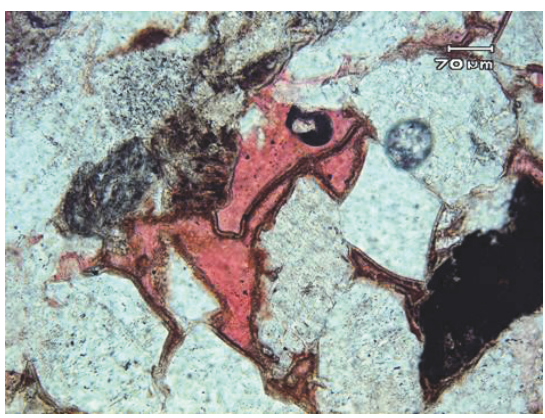

(f)

Figure 3: The lithology characteristics and reservoir pore systems of Chang 8 sandstones. (a) Medium-grained, subrounded to subangular, well sorted sandstone grains exhibit planar grain contacts, Zhuang 211, $1733.8 \mathrm{~m}$, plane-polarized light (PPL); (b) medium-grained, well sorted, framework grains are heavily compacted due to its abundance in soft rock fragments, Zhuang 211, $1714.7 \mathrm{~m}$, PPL; (c) grain contact is dominated by concave-convex due to its abundance in soft rock fragment, Yuan 177, $2466.7 \mathrm{~m}$, PPL; (d) primary intergranular pore coexisting with the moldic pore, Luo 3, $2690.75 \mathrm{~m}$, PPL; (e) porosity is shown in red, with intergranular pores, Zhuang 199, 1673.81 m, PPL; (f) primary intergranular pores showing the irregular polygon morphology, Feng 2, $2433.4 \mathrm{~m}$, PPL.

On average the sandstones are fine- to medium-grained, typically nonequant, and moderately to well sorted. The grain shape is subrounded to subangular, and the types of grain contacts are dominated by planar type (Figures 3(a) and 3(b)). However, some samples show concavo-convex grain contacts due to its abundance in soft rock fragments (Figure 3(c); [6]). Thin section analyses (presence of red epoxy) indicate that pore systems in Chang 8 oil layers are of primary and secondary origins. In addition to the remaining primary intergranular porosity (Figures 3(d), 3(e), and 3(f)), variable amounts of secondary intragranular porosity due to partial to pervasive dissolution of detrital framework grains (feldspars and rock fragments) occur in many samples (Figures 3(e) and $3(f))[6,41]$.

The lithology has a primary control on the reservoir property of the Chang 8 sandstones. Figure 4 shows the cross-plot of permeability and porosity for various lithology within the Chang 8 reservoirs. It can be concluded that the medium-grained sandstone samples have the highest average porosity and permeability, whereas the reservoir quality of the siltstones and the mudstones are poor. In contrast, the fine-grained sandstones show a wide range of porosity and permeability due to various diagenetic modifications such as carbonate cementations. Some mediumgrained sandstones also show very poor reservoir property, which are suggested to have experienced extensive carbonate cementation (Figure 4).

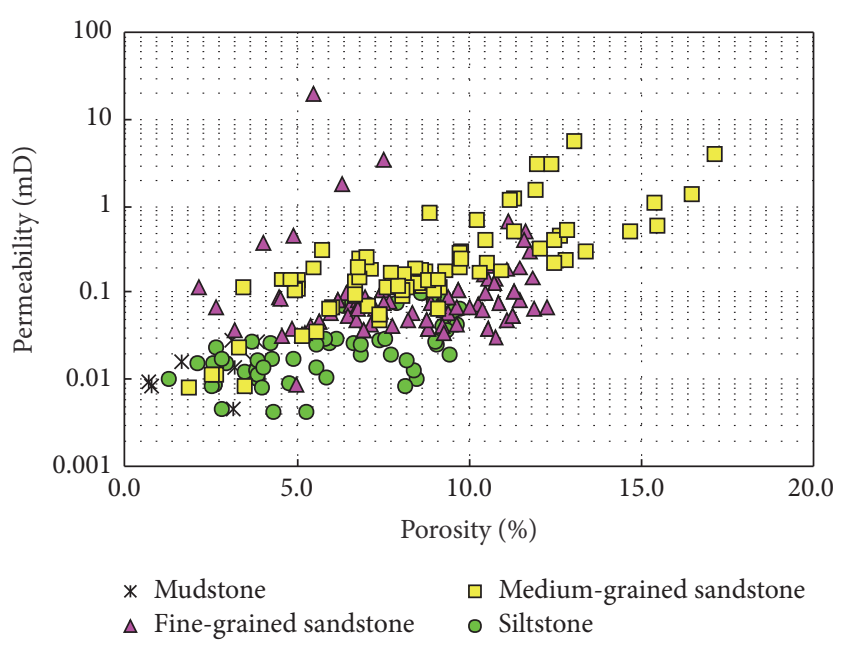

FIGURE 4: Core porosity versus core permeability cross-plots for various lithologies within Chang 8 oil layers in Ordos basin.

4.2. Carbonate Cement. Carbonate skeletal grains are rare in Chang 8 sandstones. Carbonate cementation has a profound impact on reservoir heterogeneity and quality, which often contributes to the poorest reservoir quality (Figure 5). Under microscopic observations, the total carbonate cement content in Chang 8 sandstones ranges from trace levels $(<1 \%)$ to 


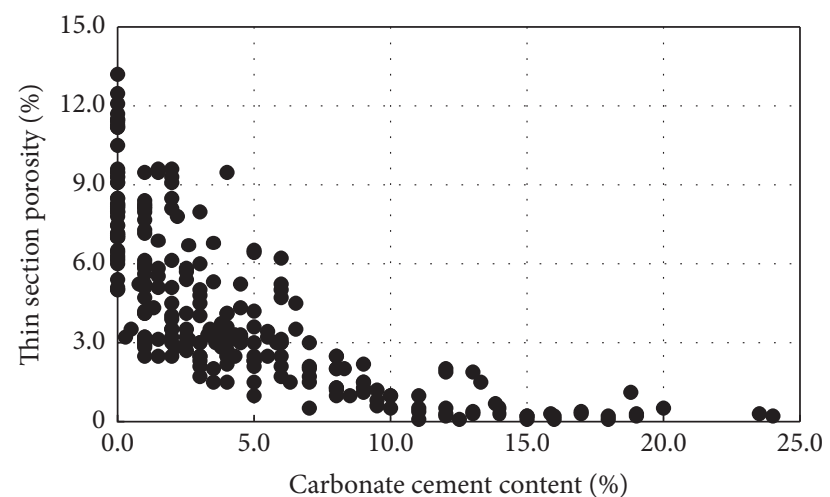

FIGURE 5: Scatter diagram showing the relationship of thin section porosity versus carbonate cement content.

$24.0 \%$ with an average of $5.1 \%$, and there is a trend that the thin section porosity would decrease rapidly with the increasing carbonate cement content (Figure 5). When the carbonate cement content is greater than $5.0 \%$, the thin section porosity became very low $(<3.0 \%)$ (Figure 5$)$, and the thin section porosity is less than $1.0 \%$ when the carbonate cement content is greater than $15.0 \%$; therefore it can be concluded that the carbonate cementation is one of the major causes contributing to the poor reservoir property in Chang 8 sandstones. Additionally, in Figure 5, there are also some samples with low content of carbonate cement but have low thin section porosity, and these samples are suggested to be those tightly compacted (Figure 5), which can be evidenced by the deformation of micas as well as the planar grain contacts (Figures 3(b) and 3(c)). According to conventional plug samples analysis, the carbonate content has also a negative impact of the core-measured porosity (Figure 6). Figure 6 exhibits core-measured porosity plotted against carbonate cement content for various lithologies within Chang 8 sandstones. Generally, the siltstones have the lowest porosity due to the extensive carbonate cement, while the carbonate cement content in fine-grained sandstones are relatively less than that in the medium-grained sandstones. Samples abundant in carbonate cement have very low porosity, which is consistent with the observations in Figure 4 . The mudstones have the lowest carbonate cement content; however, the porosity in mudstones is very low due to the extensive diagenetic modifications such as compaction (Figure 6).

Carbonate cement is commonly observed to have replaced other detrital components, such as feldspar and rock fragment grains (Figures 7(a) and 7(b); [41]). It appears that the carbonate cement as well as compaction has collectively controlled the reservoir quality evolution of sandstones [10]. Among the carbonate cement, calcite and Fe-calcite are the major cement types in Chang 8 sandstones, ranging in volume abundance from trace amounts $(<1 \%)$ to $24.0 \%$ of the rock, with an average of $3.73 \%$, while dolomites and Fe-dolomites are relatively less commonly observed (ranges: trace to $14.0 \%$, averaged as $1.37 \%$ ). According to the thin section petrography, there exist three types of carbonate

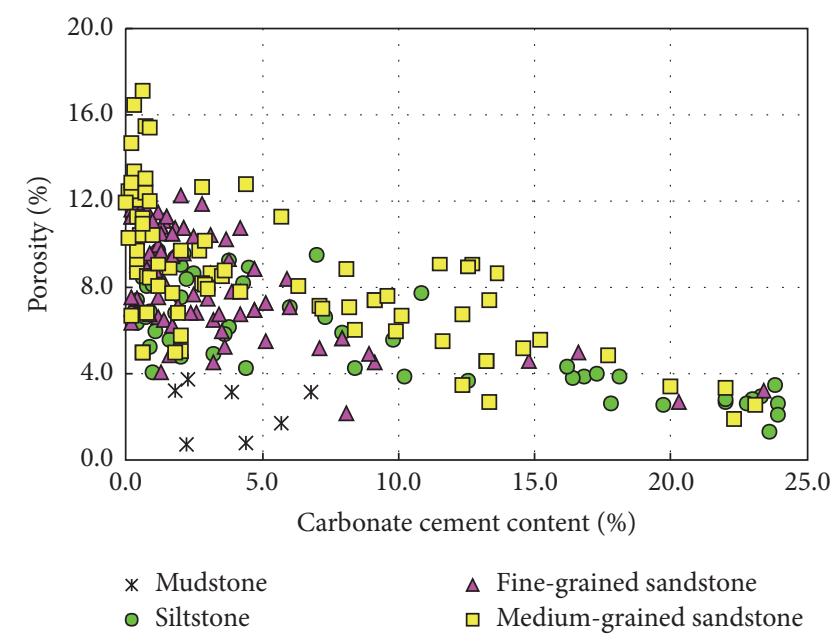

FIGURE 6: Core-measured porosity plotted against carbonate cement content of various lithology.

cement in sandstones of the Chang 8 sandstones: (1) carbonates as the dominant pore-filling constituents; (2) carbonates replacing framework grains; and (3) carbonates precipitating in intergranular pores before or after other cement types (Figures $7(\mathrm{a})-7(\mathrm{~d})$ ).

Thin section petrography and CL analysis confirm that two generations of carbonate cement are recognized and hereafter are referred to as Type I (mainly pore-filling and grain-replacing calcite and minor dolomite) and Type II (mainly grain-replacing Fe-calcite, Fe-dolomite and minor amount of calcite, and the carbonate cement precipitating in intergranular pores). Type I tends to fill the relatively large pores or replace the framework grains (Figures $7(\mathrm{c})$ and $7(\mathrm{~d})$ ) [6]. The eogenetic cement may have supported the framework grains and prevented extensive compaction [42], resulting in the floating grain texture and high volume of high minuscement porosity [43]. The pore-filling cement is suggested to have precipitated before significant compaction and thus support eogenetic origin $[44,45]$; however, the carbonate cement replacing framework grains may also precipitate after significant compaction. They display bright orange-red and yellow luminescence patterns under cathodoluminescence analysis (Figures 7(e) and 7(f)). Type II tends to occupy much smaller intergranular pores in tightly packed sandstones or, in some cases, partly and/or totally replaced the detrital grains (Figures $7(\mathrm{~g})$ and $7(\mathrm{~h})$ ). They commonly precipitate along the edge of the preexisting Type I carbonate cement, indicating precipitation after considerable compaction and thus a mesogenetic origin [44]. Petrography and CL analysis show that calcite is often replaced by ferroan calcite, indicating that the formation timing of the Fe-calcite is after that of calcite (Figures $7(\mathrm{e})-7(\mathrm{~h})$ ). Isolated Fe-calcite also occurs in intragranular feldspar dissolution pores (Figure $7(\mathrm{~g})$ ), which indicates that the reservoirs experienced dissolution before the precipitation of Fe-calcite [12]. Type II carbonates can be distinguished from Type I carbonate cement since they display weak dull red/orange colors and blotchy luminescence patterns due to the presence of Fe and Mn ions (Figures 7(i) 


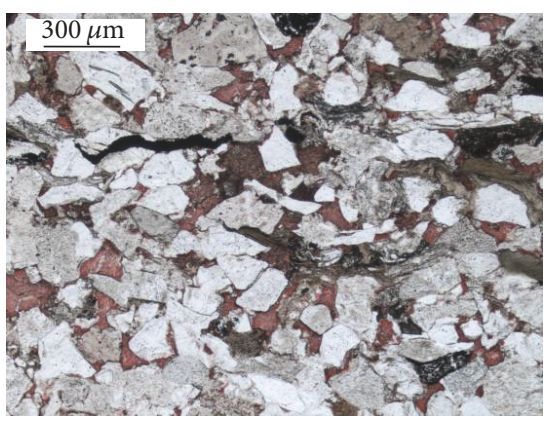

(a)

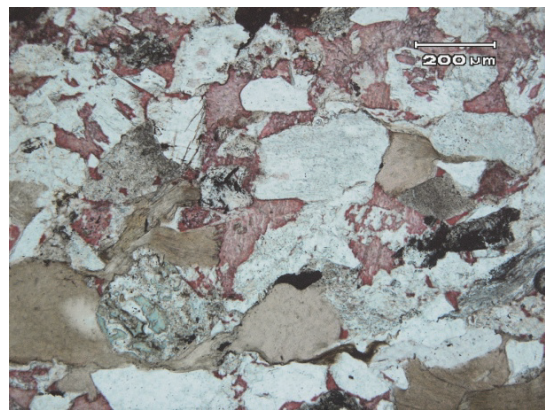

(d)

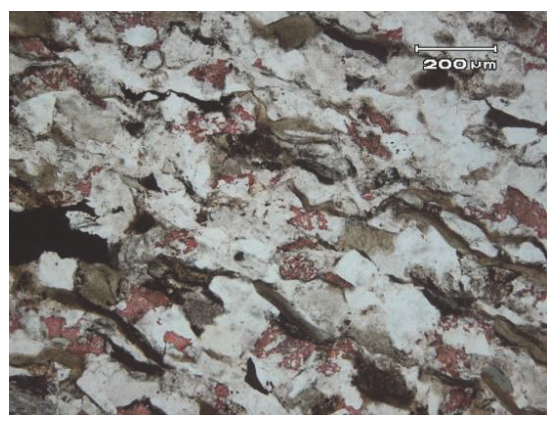

(g)

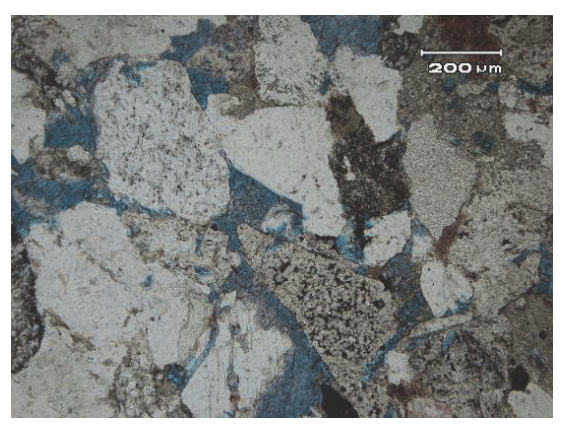

(b)

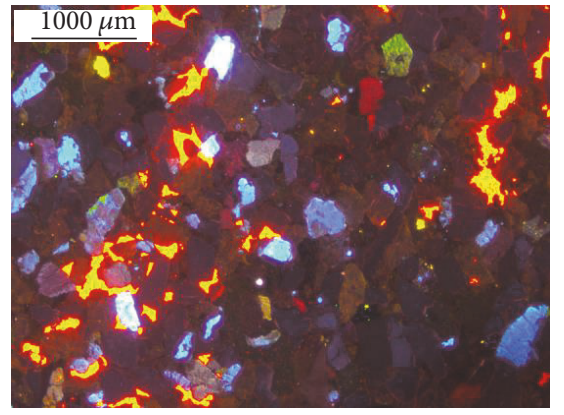

(e)

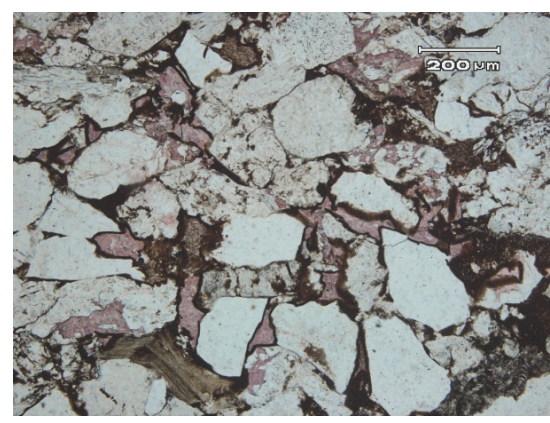

(h)

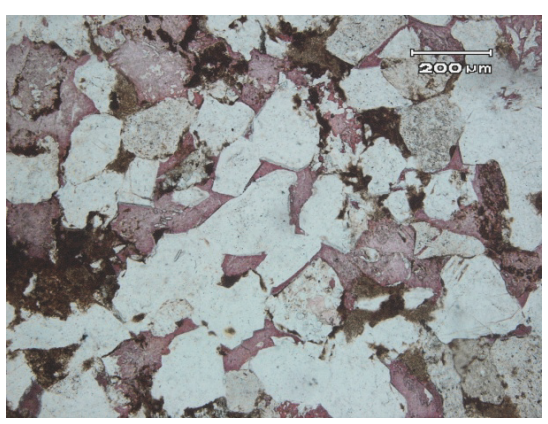

(c)

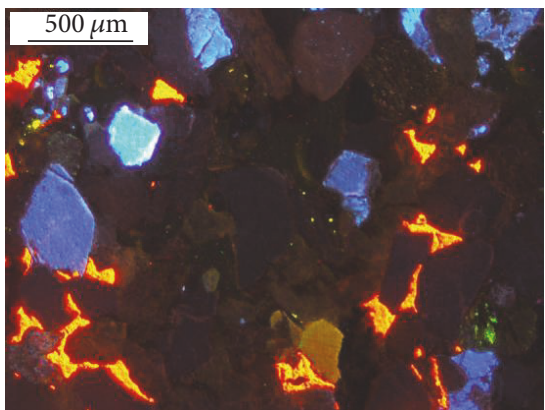

(f)

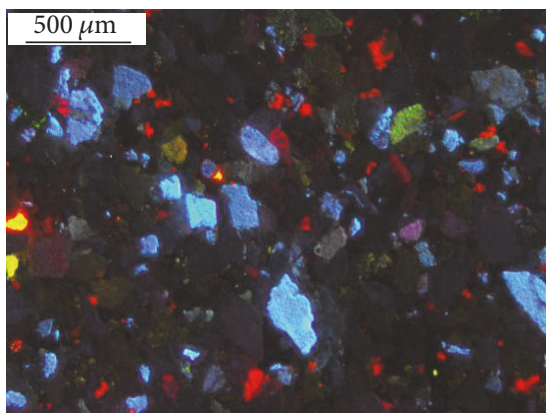

(i)

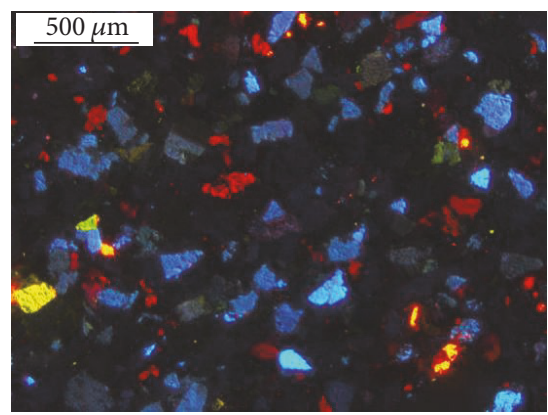

(j)

FIGURE 7: Photomicrographs showing the petrography, geochemistry, and distribution of carbonate cement for Chang 8 sandstones in Ordos basin; (a) calcites are the dominant pore-filling constituents, and they also replace framework grains; intergranular macropores are rarely observed in this sandstone, Zhuang 75, $2116 \mathrm{~m}$, PPL; (b) dolomites are the most common pore-filling constituents. Dolomite also replaces framework grains, Yuan 43, $2270.56 \mathrm{~m}$, PPL; (c) calcite fills large intergranular pores between loosely packed framework grains and replaces the framework grains, Luo 1, $2499.07 \mathrm{~m}$; (d) calcite fills large intergranular pores between loosely packed framework grains and replaces the framework grains, Feng 9, $2512.92 \mathrm{~m}$; (e) Type I calcites fill large pores between loosely packed framework grains, which display bright orange-red and yellow luminescence patterns, Zhuang 214, $1890.37 \mathrm{~m}$, Cathode Luminescence (CL); (f) Type I calcites display bright orangered and yellow luminescence patterns, Zhuang 214, $1890.37 \mathrm{~m}$, CL; (g) Type II calcites occupy much smaller intergranular pores in tightly packed sandstones and replaced the detrital grains, An 62, $2396.47 \mathrm{~m}$, PPL; (h) Type II calcites occupy much smaller intergranular pores in tightly packed sandstones and replaced the detrital grains, Luo 13, 2750.62, PPL; (i) Type II calcites occupy much smaller intergranular pores in tightly packed sandstones, and they precipitate along the edge of the preexisting Type I carbonate cement, and they display a weak dull red/orange and blotchy luminescence, Zhuang 240, $1785.6 \mathrm{~m}$, CL; (j) Type II calcites display a weak dull red/orange and blotchy luminescence, Zhuang 214, 1782.85 m, CL. 


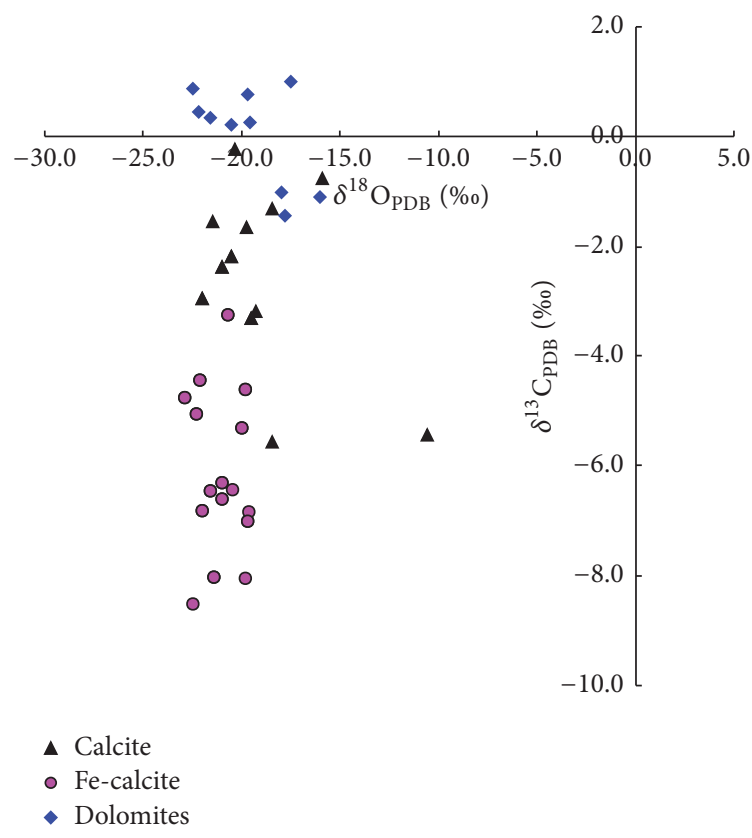

FIGURE 8: Scatter diagram showing the oxygen versus carbon stable isotopes for all types of carbonate cement of Yanchang Formation sandstones in Ordos basin (after [27-30]).

and $7(\mathrm{j}))$. Thin section analysis shows that no dissolution of carbonate cement is observed.

\section{Discussions}

5.1. Isotope Analysis and Origins of Carbonate Cement. Determining the origin of carbonate cement can improve our ability to predict its distribution (Liu et al., 2015). Bulk isotopic signature of carbonate cement would provide some additional clues to clarify their origin $[43,46]$. According to the results published by Shi et al. [29], Wang et al. [30], Zhixue et al. [27], and Tian et al. [28], the $\delta^{13} \mathrm{C}$ values (PDB) are in the range from $-8.51 \%$ o to $1.00 \%$ with an average of $-3.55 \%$, whereas the $\delta^{18} \mathrm{O}$ values (PDB) range from $-22.9 \%$ to $-10.58 \%$ and have an average of $-19.62 \%$ (Figure 8 ).

The isotope analysis shows that the carbonate cement has relatively lighter oxygen and carbon isotopes. The negative $\delta^{13} \mathrm{C}$ values could be attributed to a variety of sources and/or processes, such as the derivation of carbon from thermal maturation of organic matter during burial $[10,47,48]$.

All the carbonate cement types have very negative $\delta^{18} \mathrm{O}$ values (Figure 8). Depletion of $\delta^{18} \mathrm{O}$ in carbonates is attributed to (i) incursion of meteoric water; (ii) precipitation and recrystallization at higher temperatures; and (iii) microbial fractionation of oxygen isotopes [44]. Lighter oxygen isotopes and negative $\delta^{13} \mathrm{C}$ values in Chang 8 sandstones may suggest the role of freshwater influence on carbonates development. However, the Yanchang Formation had been continuously buried to larger than $2 \mathrm{~km}$ since its initial deposition (Figure 2), and there are no unconformities developed in the Chang 8 sandstones; therefore the Chang 8 sandstones had never been exposed to surface and meteoric flushing. In contrast, reprecipitation and recrystallization during burial (increase in burial and temperature) would lead to a further negative shift in $\delta^{18} \mathrm{O}$ values [49]. The high ${ }^{18} \mathrm{O}-$ depleted signature, negative $\delta^{13} \mathrm{C}$ values, and high $\mathrm{Fe}$ and $\mathrm{Mg}$ contents suggest that the late replacive carbonate cement (Fe-calcite and Fe-dolomite) including $\mathrm{Fe}$-dolomite and $\mathrm{Fe}$ calcite formed in burial conditions via the replacement of early diagenetic carbonate cement by the influence of deep formation water [45]. The positive $\delta^{13} \mathrm{C}$ values of some dolomite cement in Chang 8 sandstones are compatible with early marine carbonates but not the oxygen isotopes (Figure 8; [27]).

5.2. Paragenetic Sequence of Carbonate Cement. It is difficult to define precisely the timing of the cementation processes $[45,50]$. Two diagenetic stages of carbonate cement are recognized according to petrographic and textural relationships and elemental and stable isotopic composition: the early diagenetic stage in shallow depth, represented by porefilling and grain-replacing calcite and dolomite, and the late mesogenetic deep burial diagenetic stage, represented by ferroan calcite and ferroan dolomite replacing framework grains and precipitating in intergranular pores. Eogenetic diagenetic alterations also include mechanical compaction and formation of kaolinite and grain-coating chlorites, while mesogenetic diagenesis is characterized by continued mechanical compaction, dissolution of framework grain by organic acids, and subsequent precipitation of quartz and clay minerals such as illite and mixed-layer illite/smectite (Figure 9). Immediately after deposition, the mechanical compaction occurred, resulting in a significant reduction in the intergranular porosity [51]. Then grain-coating chlorites formed, and some kaolinites precipitated due to feldspar alteration. In mesodiagenesis, mechanical compaction continued to reduce the intergranular porosity. With progressive burial and increasing temperature, organic acids charged into the reservoirs, and feldspars were dissolved to form intragranular dissolution pores [4]. As the byproducts of feldspar dissolution, the quartz cement and clay minerals such as illite and mixed-layer illite/smectite precipitated (Figure 9; [6]).

The presence of carbonate cement in the loosely packed framework grains indicates that cementation commenced shortly after deposition [45]. The slightly negative $\delta^{13} \mathrm{C}$ values of the dolomite and calcite cement would indicate its precipitation in slightly reducing conditions with minor contribution of organic carbon derived from soil-derived $\mathrm{CO}_{2}$ [45]. Indeed, soil $\mathrm{CO}_{2}$ could also give the depleted $\delta^{13} \mathrm{C}$ values, and it depends on how much soil $\mathrm{CO}_{2}$ was incorporated into the diagenetic fluids.

With progressive burial, the late-stage ferroan calcite and ferroan dolomite formed (Figures 7(e) and 7(f)). Under CL analysis, the early diagenetic carbonate cement is commonly observed to be partially to completely replaced by ferroan calcite and ferroan dolomite (Figures $7(\mathrm{~g})$ and $7(\mathrm{~h})$ ). Alteration of eogenetic carbonate cement by fluids rich in Fe and/or $\mathrm{Mg}$ is regarded as a source of late precipitation of Type II carbonates during burial [45]. The Chang 8 sandstones had been buried deeper than $2000 \mathrm{~m}$ and were suggested to have 


\begin{tabular}{|c|c|c|c|c|c|c|c|}
\hline Diagenetic stage & \multicolumn{3}{|c|}{ Eodiagenesis } & \multicolumn{4}{|c|}{ Mesodiagenesis } \\
\hline Temperature $\left({ }^{\circ} \mathrm{C}\right)$ & \multicolumn{2}{|l|}{$10-25$} & 70 & & & & 120 \\
\hline Age (Ma) & 208 & & \multicolumn{2}{|r|}{135} & \multicolumn{2}{|r|}{65} & 0 \\
\hline Epoch & $\mathrm{T}_{3}$ & $\mathbf{J}_{1}$ & $\mathbf{J}_{2}$ & $\mathbf{J}_{3}$ & $\mathbf{K}_{1}$ & $\mathbf{K}_{2}$ & $\mathbf{E}+\mathbf{Q}$ \\
\hline Compaction & \multicolumn{7}{|c|}{ 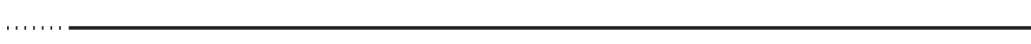 } \\
\hline Kaolinite & \multicolumn{7}{|c|}{$\ldots \ldots \ldots$} \\
\hline Quartz & \multicolumn{7}{|c|}{$\ldots \ldots \ldots \downarrow$} \\
\hline I/S mixed layer & \multicolumn{7}{|c|}{$\ldots \ldots, \square=\ldots \ldots$} \\
\hline Illite & \multicolumn{7}{|r|}{$\ldots \ldots$} \\
\hline Chlorite & \multicolumn{7}{|c|}{ - $\ldots . . .}$. \\
\hline Calcite and Fe-calcite & \multicolumn{7}{|c|}{$\ldots \ldots \ldots$} \\
\hline Dolomite and Fe-dolomite & \multicolumn{7}{|c|}{$\ldots \ldots \ldots$} \\
\hline Dissolution & & & . & $\ldots$ & & 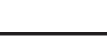 & -. \\
\hline
\end{tabular}

Figure 9: Paragenetic sequence of diagenesis in the Chang 8 sandstones in west Ordos basin. The boundary between eodiagenesis and mesodiagenesis is according to Morad et al. [31].

experienced various types and degrees of diagenesis such as compaction, cementation, and dissolution during the long geological history. The isotopic composition may also be modified during burial diagenesis, such as thermal evolution of organic matters during progressive burial and increasing temperature [52].

5.3. Distribution Patterns of Carbonate Cement. As discussed above, no carbonate rock fragments are observed in thin sections; therefore the carbonates detected by ECS logs are mainly cement. According to the interpretation results of ECS data, there is a downward decrease in the abundance of carbonate cement in Chang 8 sandstones (Figures 10 and 11). The tight carbonate cemented zones with carbonate cement greater than $10 \%$ are relatively shallowly buried and more adjacent to the overlying Chang 7 source rocks. With increasing distance from the Chang 7 oil layer, the carbonate cement content gradually decreases (Figures 10 and 11). However, there are also some carbonate cementation zones further down, and these layers with high percentage of carbonate cement are mainly associated with the sandstonemudstone contacts (Figures 10 and 11), for example, the 2345-2350 m depth intervals in Figure 10 and 2528-2529 m depth intervals in Figure 11. Areas that have high percentages of carbonate cemented sandstones often occur along the margins of the sandstone bodies, where sandstone pinches out into mudstone $[9,53]$. Since sandstone reservoirs interbedded with mudstones are readily influenced by a variety of sources of fluids, the sandstone-mudstone interface is the area with strong water-rock interactions $[11,12]$.

Diagenetic mineral assemblages from ECS logging data show that carbonate cement has a highly zonal distribution, confined to thin beds or concretions in general, and the carbonate cement is much more commonly observed in sand bodies which are adjacent with the Chang 7 source rocks (Figures 10 and 11). Type I carbonates precipitated at eogenetic stage in the whole Chang 8 sandstones, resulting in the highly zonal distribution of carbonate cement, while the late-stage carbonate cement is mainly associated with the mudrocks of Chang 7 oil layer. Carbon isotope of $\mathrm{CO}_{2}$ from volcanic rock is between -5 and $+7 \%$; from carbonate decomposition is between -3.5 and $+3.57 \%$; from carbonate cement of mudstones should be between -15 and $-9 \%$; from the thermal evolution of organic matter should be $-20 \%$ or so and even more negative $[54,55]$. By isotope analysis (Figure 8), it can be concluded that the Fe-calcite should come from the carbonate cement source of mudrocks. Particularly the late-stage carbonate cement (Fe-calcite and Fe-dolomite) is mainly associated with release of acidic fluids from the mudrock intervals. Organic acid generations from mudrocks during late-stage burial would result in a reducing environment, which is favorable for the late-stage carbonate cementations [56]. Therefore these late carbonate (Fe-calcite and $\mathrm{Fe}$-dolomite) cement types are related to thermal evolution of mudrocks and the availability of $\mathrm{Ca}^{2+}$, $\mathrm{Mg}^{2+}$, and $\mathrm{Fe}^{2+}$ in the formation water (e.g., [57]).

The mudstones and oil shales of the Chang 7 oil layers are thought to be the best source rocks for Chang 8 sandstone reservoirs $[35,37]$. The organic acids and $\mathrm{CO}_{2}$ generated by thermal maturation of these source rocks would firstly charge into the sandstones adjacent to Chang 7 mudstones and shales, and these organic acids and $\mathrm{CO}_{2}$ are mostly buffered by feldspar (especially Ca-feldspar grains) and rock fragments (the $\mathrm{pH}$ would be buffered by silicates) in sand 


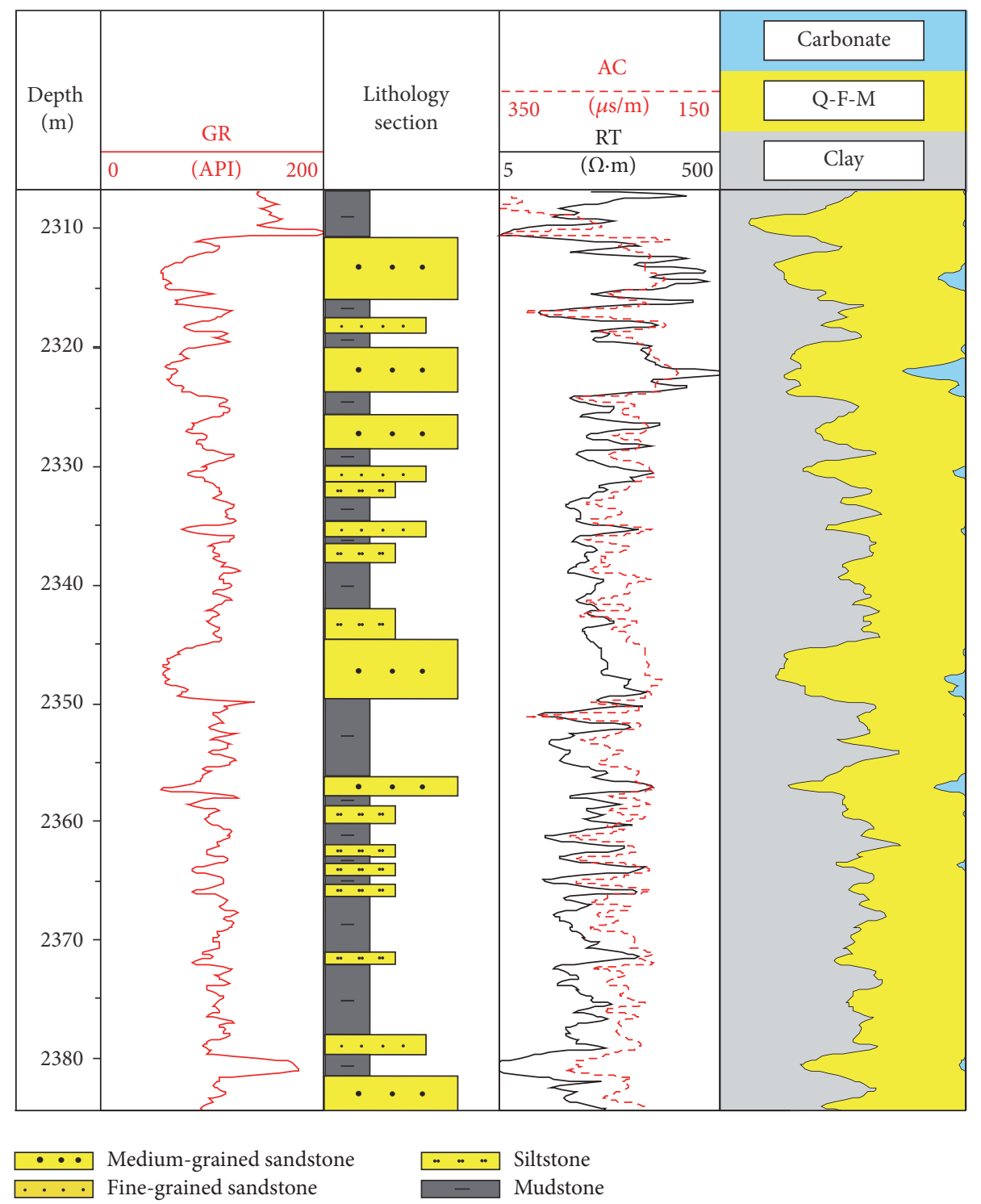

FIGURE 10: Diagenetic mineral assemblage characteristics interpreted by ECS logging in Well 22.

bodies adjacent to the Chang 7 oil layers. Feldspar dissolution pores are commonly observed while the carbonates show no evidence of dissolution (Figures 3(d), 3(e), and 3(f)). Besides the dissolution of Ca-feldspars, clay mineral transformations such as illitization of smectite are also accompanied by a release of $\mathrm{Ca}^{2+}$ and $\mathrm{Mg}^{2+}$ into solution [12, 53]. Carbonate cement (mainly Type II) would precipitate with enrichment of $\mathrm{Ca}^{2+}$ and $\mathrm{Mg}^{2+}$ ions and a decrease in $\mathrm{CO}_{2}$ concentration under $\mathrm{Fe}$ - and $\mathrm{Mn}$-reducing, suboxic to sulfate-reduction geochemical conditions [57-60]. With increasing burial depth and temperature, the decomposition of organic acid decarboxylation would be enhanced, and more clay mineral transformation would occur [12]. The sand bodies which are more adjacent to the overlying Chang 7 mudrocks are more favorable for the late-stage carbonate cementation. These carbonate cement types will fill porosity where framework grains were previously dissolved.

\section{Conclusions}

(1) Two generations of carbonate cement were recognized as Type I (calcite and dolomite) and Type II (mainly Fe-calcites and Fe-dolomites).

(2) Carbonate cement is closely related to the dissolved carbon from thermal maturation of organic matters. High-temperature burial diagenesis would lead to a further negative shift in $\delta^{18} \mathrm{O}$ values.

(3) Carbonate cement is much more commonly observed in sand bodies adjacent to Chang 7 source rocks. Dissolution of Ca-feldspars by organic acids-rich fluids, together with illitization of smectite, provides $\mathrm{Ca}^{2+}$ and $\mathrm{Mg}^{2+}$ ions for carbonate cementation, and carbonate cement would precipitate with a decrease in $\mathrm{CO}_{2}$ concentration. 


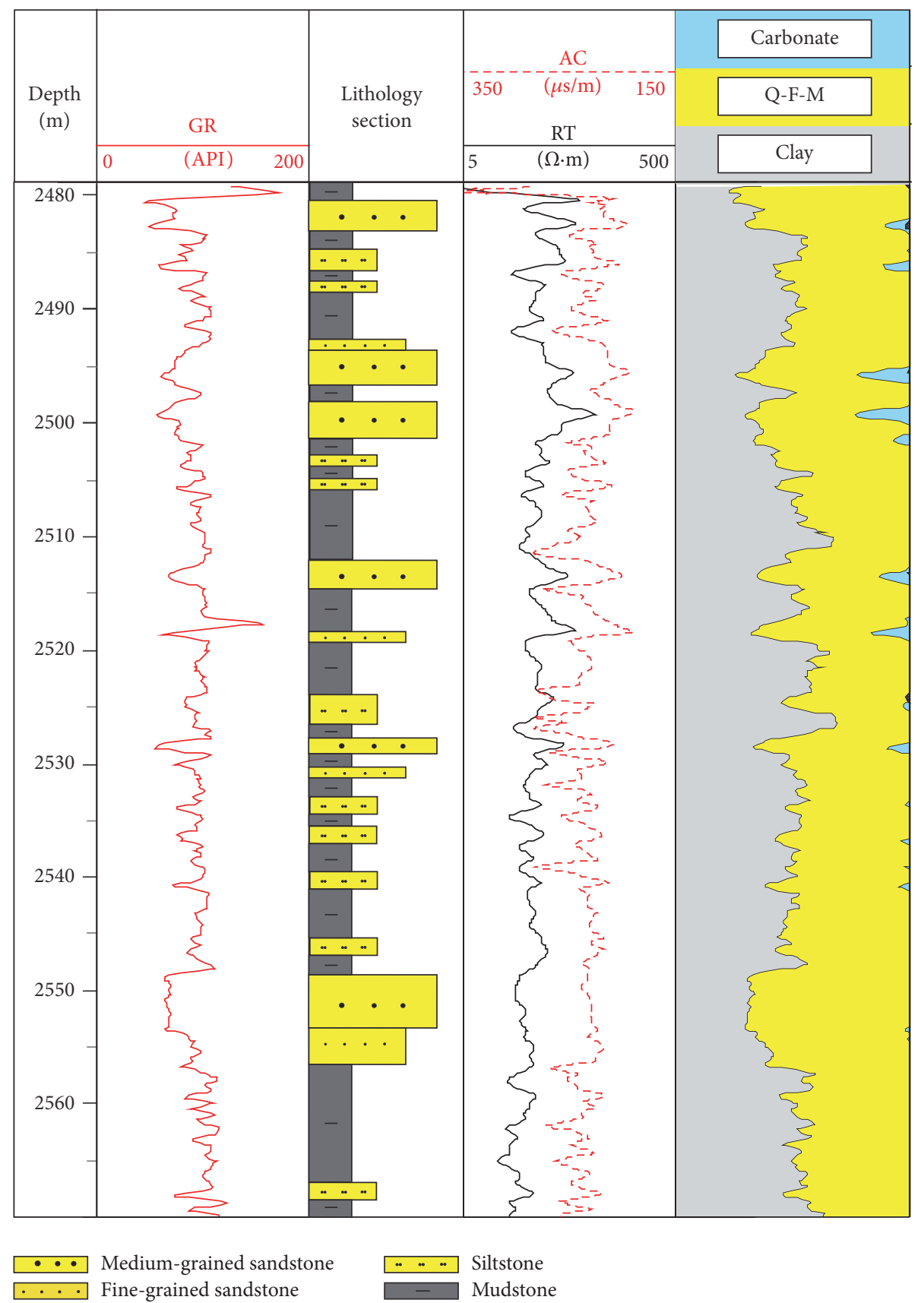

FIGURE 11: Diagenetic mineral assemblage characteristics interpreted by ECS logging in Well 157.

\section{Conflicts of Interest}

No conflicts of interest exist in the submission of this manuscript.

\section{Acknowledgments}

The authors acknowledge PetroChina Changqing Oilfield Company and PetroChina Research Institute of Petroleum Exploration and Development for providing samples and data access and for permission to publish this work. This study was supported by the National Natural Science Foundation of China (no. 41472115) and Science Foundation of China University of Petroleum, Beijing (no. 2462017YJRC023). The authors thank Professor Zhiqiang Mao and Professor Yujiang Shi for their data support.

\section{References}

[1] H. Zhu, K. Chen, K. Liu, and S. He, "A sequence stratigraphic model for reservoir sand-body distribution in the Lower Permian Shanxi Formation in the Ordos Basin, northern China," 
Marine and Petroleum Geology, vol. 25, no. 8, pp. 731-743, 2008.

[2] C. Zou, L. Wang, Y. Li, S. Tao, and L. Hou, "Deep-lacustrine transformation of sandy debrites into turbidites, Upper Triassic, Central China," Sedimentary Geology, vol. 265-266, pp. 143-155, 2012.

[3] L.-M. Ji, F.-W. Meng, J. D. Schiffbauer, J.-L. Xu, K. Yan, and J.-W. Shu, "Correlation between highly abundant oil-prone leiosphaerid acritarchs and hydrocarbon source rocks from the Triassic Yanchang Formation, eastern Gansu Province, Northwestern China," Gondwana Research, vol. 14, no. 3, pp. 554-560, 2008.

[4] G. Wang, X. Chang, W. Yin, Y. Li, and T. Song, "Impact of diagenesis on reservoir quality and heterogeneity of the Upper Triassic Chang 8 tight oil sandstones in the Zhenjing area, Ordos Basin, China," Marine and Petroleum Geology, vol. 83, pp. 84-96, 2017.

[5] L. Rongxi, T. Guzmics, L. Xiaojie, and X. Guangcheng, "Migration of immiscible hydrocarbons recorded in calcite-hosted fluid inclusions, Ordos Basin: a case study from Northern China," Russian Geology and Geophysics, vol. 52, no. 11, pp. 14911503, 2011.

[6] J. Lai, G. Wang, Y. Chai, and Y. Ran, "Prediction of diagenetic facies using well logs: evidences from Upper Triassic Yanchang Formation Chang 8 sandstones in Jiyuan region, Ordos basin, China," Oil \& Gas Science and Technology-Rev. IFP Energies nouvelles, vol. 71, article 34, 2016.

[7] X. Luo, J. Yu, L. Zhang et al., "Numerical modeling of secondary migration and its applications to Chang-6 Member of Yanchang Formation (Upper Triassic), Longdong area, Ordos Basin, China," Science in China, Series D: Earth Sciences, vol. 50, no. 2, pp. 91-102, 2007.

[8] Y. Cui, G. Wang, S. J. Jones et al., "Prediction of diagenetic facies using well logs-a case study from the upper Triassic Yanchang Formation, Ordos Basin, China," Marine and Petroleum Geology, vol. 81, pp. 50-65, 2017.

[9] S. P. Dutton, "Calcite cement in permian deep-water sandstones, delaware basin, west Texas: origin, distribution, and effect on reservoir properties," AAPG Bulletin, vol. 92, no. 6, pp. 765-787, 2008.

[10] H. Mansurbeg, S. Morad, A. Salem et al., "Diagenesis and reservoir quality evolution of palaeocene deep-water, marine sandstones, the Shetland-Faroes Basin, British continental shelf," Marine and Petroleum Geology, vol. 25, no. 6, pp. 514-543, 2008.

[11] S. J. Loyd, F. A. Corsetti, J. M. Eiler, and A. K. Tripati, "Determining the diagenetic conditions of concretion formation: assessing temperatures and pore waters using clumped isotopes," Journal of Sedimentary Research, vol. 82, no. 12, pp. 1006-1016, 2012.

[12] J. Wang, Y. Cao, K. Liu, J. Liu, X. Xue, and Q. Xu, "Pore fluid evolution, distribution and water-rock interactions of carbonate cements in red-bed sandstone reservoirs in the Dongying Depression, China," Marine and Petroleum Geology, vol. 72, pp. 279-294, 2016.

[13] K. G. Taylor, R. L. Gawthorpe, C. D. Curtis, J. D. Marshall, and D. N. Awwiller, "Carbonate cementation in a sequence-stratigraphic framework: upper cretaceous sandstones, book cliffs, utah-colorado," Journal of Sedimentary Research, vol. 70, no. 2 , pp. 360-372, 2000.

[14] A. A. Taghavi, A. Mørk, and M. A. Emadi, "Sequence stratigraphically controlled diagenesis governs reservoir quality in the carbonate Dehluran Field, southwest Iran," Petroleum Geoscience, vol. 12, no. 2, pp. 115-126, 2006.
[15] Q. Liu, L. Chan, Q. Liu et al., "Relationship between magnetic anomalies and hydrocarbon microseepage above the Jingbian gas field, Ordos basin, China," AAPG Bulletin, vol. 88, no. 2, pp. 241-251, 2004.

[16] J. Li, W. Zhang, X. Luo, and G. Hu, "Paleokarst reservoirs and gas accumulation in the Jingbian field, Ordos Basin," Marine and Petroleum Geology, vol. 25, no. 4-5, pp. 401-415, 2008.

[17] X. Qiu, C. Liu, G. Mao, Y. Deng, F. Wang, and J. Wang, "Late Triassic tuff intervals in the Ordos basin, Central China: their depositional, petrographic, geochemical characteristics and regional implications," Journal of Asian Earth Sciences, vol. 80, pp. 148-160, 2014.

[18] J. Lai, G. Wang, M. Chen et al., "Pore structures evaluation of low permeability clastic reservoirs based on petrophysical facies: a case study on Chang 8 reservoir in the Jiyuan region, Ordos Basin," Petroleum Exploration and Development, vol. 40, no. 5, pp. 566-573, 2013.

[19] L.-M. Ji, K. Yan, F.-W. Meng, and M. Zhao, “The oleaginous Botryococcus from the Triassic Yanchang Formation in Ordos Basin, Northwestern China: morphology and its paleoenvironmental significance," Journal of Asian Earth Sciences, vol. 38, no. 5, pp. 175-185, 2010.

[20] Z. Jiang, J. Xu, and G. Wang, "The discovery and significance of a sedimentary hiatus within the Carboniferous Taiyuan Formation, northeastern Ordos Basin, China," AAPG Bulletin, vol. 96, no. 7, pp. 1173-1195, 2012.

[21] S. Guo, "Experimental study on isothermal adsorption of methane gas on three shale samples from Upper Paleozoic strata of the Ordos Basin," Journal of Petroleum Science and Engineering, vol. 110, pp. 132-138, 2013.

[22] C.-Y. Wang, E. Sandvol, L. Zhu, H. Lou, Z. Yao, and X. Luo, "Lateral variation of crustal structure in the Ordos block and surrounding regions, North China, and its tectonic implications," Earth and Planetary Science Letters, vol. 387, pp. 198-211, 2014.

[23] Z. Xu, L. Liu, T. Wang et al., "Characteristics and controlling factors of lacustrine tight oil reservoirs of the Triassic Yanchang Formation Chang 7 in the Ordos Basin, China," Marine and Petroleum Geology, vol. 82, pp. 265-296, 2017.

[24] J. Lai, G. Wang, Y. Ran, Z. Zhou, and Y. Cui, "Impact of diagenesis on the reservoir quality of tight oil sandstones: The case of Upper Triassic Yanchang Formation Chang 7 oil layers in Ordos Basin, China," Journal of Petroleum Science and Engineering, vol. 145, pp. 54-65, 2016.

[25] Z. Cao, G. Liu, H. Zhan et al., "Pore structure characterization of Chang-7 tight sandstone using MICP combined with $\mathrm{N}^{2}$ GA techniques and its geological control factors," Scientific Reports, vol. 6, Article ID 36919, 2016.

[26] B. Shi, Y. Zhang, L. Zhang, Y. Yang, and H. Li, "Hydrocarbon accumulation dating by fluid inclusion characteristics in Chang 7 tight sandstone reservoirs of Yanchang Formation in Ordos Basin," Petroleum Exploration and Development, vol. 34, no. 6, pp. 599-603, 2012.

[27] S. Zhixue, S. Zhilei, L. Hongjiang, and Y. Xijie, "Characteristics of carbonate cements in sandstone reservoirs: a case from Yanchang Formation, middle and southern Ordos Basin, China," Petroleum Exploration and Development, vol. 37, no. 5, pp. 543551, 2010.

[28] Y. Tian, Z. Shi, and J. Song, "Characteristics of carbonate cements of Member 8 of Yanchang Formation in the YichuanXunyi area, Ordos Basin, China," Journal of Chengdu University of Technology, vol. 38, no. 4, pp. 378-384, 2011. 
[29] J. Shi, J. Wang, M. Mao et al., "Reservoir sandstone diagenesis of Memeber 6 to 8 in Yanchang Formation (Triassic), Xifeng oilfield, Ordos basin," Acta Sedimentologica Sinica, vol. 21, no. 3, pp. 373-380, 2003.

[30] Q. Wang, X. Zhuo, G. Chen, and X. Li, "Characteristics of carbon and oxygen isotopoc compositions of carbonate cements in Triassic Yanchang sandstone in Ordos basin," Natural Gas Industry, vol. 27, no. 10, pp. 28-34, 2007.

[31] S. Morad, J. M. Ketzer, and L. R. De Ros, "Spatial and temporal distribution of diagenetic alterations in siliciclastic rocks: implications for mass transfer in sedimentary basins," Sedimentology, vol. 47, supplement 1, pp. 95-120, 2000.

[32] M. Yang, L. Li, J. Zhou et al., "Structural Evolution and Hydrocarbon Potential of the Upper Paleozoic Northern Ordos Basin, North China," Acta Geologica Sinica, vol. 89, no. 5, pp. 1636-1648, 2015.

[33] Y. Lei, X. Luo, X. Wang et al., "Characteristics of silty laminae in Zhangjiatan shale of southeastern Ordos Basin, China: implications for shale gas formation," AAPG Bulletin, vol. 99, no. 4, pp. 661-687, 2015.

[34] W. Lyu, L. Zeng, Z. Liu, G. Liu, and K. Zu, "Fracture responses of conventional logs in tight-oil sandstones: a case study of the Upper Triassic Yanchang Formation in southwest Ordos Basin, China," AAPG Bulletin, vol. 100, no. 9, pp. 1399-1417, 2016.

[35] Y. Duan, "Geochemical characteristics of crude oil in fluvial deposits from maling oilfield of ordos basin, China," Organic Geochemistry, vol. 52, pp. 35-43, 2012.

[36] Y. Duan, Y. Yuan, and R. Qian, "Migration features of crude oil in fluvial deposits of Maling oilfield in Ordos Basin, China," Organic Geochemistry, vol. 58, pp. 78-85, 2013.

[37] L. M. Ji, F. W. Meng, T. Wu, J. L. Xu, and L. T. Li, "Fluorescence intensity in Triassic acritarchs from the Yanchang Formation of the Ordos Basin, Northwestern China," Acta Micropalaeontologica Sinica, vol. 23, no. 3, pp. 309-312, 2006.

[38] C. Zou, S. Tao, X. Yuan et al., "The formation conditions and distribution characteristics of continuous petroleum accumulations," Acta Petrolei Sinica, vol. 30, no. 3, pp. 324-331, 2009.

[39] R. G. Maliva, E. A. Clayton, and T. M. Missimer, "Application of advanced borehole geophysical logging to managed aquifer recharge investigations," Hydrogeology Journal, vol. 17, no. 6, pp. 1547-1556, 2009.

[40] H.-L. Wu, N. Li, C.-L. Lan, X.-Z. Kong, and H. Chai, "Standard spectrum measurement and simulation of elemental capture spectroscopy log," Applied Geophysics, vol. 10, no. 1, pp. 109-116, 2013.

[41] J. Lai, G. Wang, Y. Chai et al., "Mechanism analysis and quantitative assessment of pore structure for tight sandstone reservoirs: an example from Chang 8 oil layer in the Jiyuan area of Ordos basin," Acta Geologica Sinica, vol. 88, no. 11, pp. 2119-2130, 2014.

[42] F. H. Nader, E. De Boever, M. Gasparrini et al., "Quantification of diagenesis impact on the reservoir properties of the Jurassic Arab D and C members (Offshore, U.A.E.)," Geofluids, vol. 13, no. 2, pp. 204-220, 2013.

[43] J. Lai, G. Wang, Y. Chai et al., "Deep burial diagenesis and reservoir quality evolution of high-temperature, high-pressure sandstones: Examples from Lower Cretaceous Bashijiqike Formation in Keshen area, Kuqa depression, Tarim basin of China," AAPG Bulletin, vol. 101, no. 06, pp. 829-862, 2017.

[44] M. A. K. El-ghali, H. Mansurbeg, S. Morad, I. Al-Aasm, and G. Ajdanlisky, "Distribution of diagenetic alterations in fluvial and paralic deposits within sequence stratigraphic framework: evidence from the Petrohan Terrigenous Group and the Svidol Formation, Lower Triassic, NW Bulgaria," Sedimentary Geology, vol. 190, no. 1-4, pp. 299-321, 2006.

[45] A. S. Mansour, R. I. Rifai, and M. N. Shaaban, "Geochemical constraint on the origin of the multi-mineralogic carbonate cements in the subsurface Middle Jurassic sandstones, Central Sinai, Egypt," Journal of Geochemical Exploration, vol. 143, pp. 163-173, 2014.

[46] R. Calvo, A. Ayalon, A. Bein, and E. Sass, "Chemical and isotopic composition of diagenetic carbonate cements and its relation to hydrocarbon accumulation in the Heletz-Kokhav oil field (Israel)," Journal of Geochemical Exploration, vol. 108, no. 1, pp. 88-98, 2011.

[47] J. M. Ketzer, M. Holz, S. Morad, and I. S. Al-Aasm, "Sequence stratigraphic distribution of diagenetic alterations in coalbearing, paralic sandstones: evidence from the Rio Bonito Formation (early Permian), southern Brazil," Sedimentology, vol. 50, no. 5, pp. 855-877, 2003.

[48] B. Cao, X. Luo, L. Zhang, F. Sui, H. Lin, and Y. Lei, "Diagenetic evolution of deep sandstones and multiple-stage oil entrapment: a case study from the Lower Jurassic Sangonghe Formation in the Fukang Sag, central Junggar Basin (NW China)," Journal of Petroleum Science and Engineering, vol. 152, pp. 136-155, 2017.

[49] M. I. Odigi and L. C. Amajor, "Geochemistry of carbonate cements in Cretaceous sandstones, southeast Benue Trough, Nigeria: implications for geochemical evolution of formation waters," Journal of African Earth Sciences, vol. 57, no. 3, pp. 213226, 2010.

[50] J. Lai, G. Wang, C. Cai et al., "Diagenesis and reservoir quality in tight gas sandstones: the fourth member of the Upper Triassic Xujiahe Formation, Central Sichuan Basin, Southwest China," Geological Journal, pp. 1-18, 2017.

[51] J. Lai, G. Wang, Y. Ran, and Z. Zhou, "Predictive distribution of high-quality reservoirs of tight gas sandstones by linking diagenesis to depositional facies: evidence from $\mathrm{Xu}-2$ sandstones in the Penglai area of the central Sichuan basin, China," Journal of Natural Gas Science and Engineering, vol. 23, pp. 97-111, 2015.

[52] S. M. Zamanzadeh, A. Amini, and M. Ghavidel-Syooki, "Sequence stratigraphic controls on early-diagenetic carbonate cementation of shallow marine clastic sediments (the Devonian Zakeen Formation, southern Zagros, Iran)," Geosciences Journal, vol. 13, no. 1, pp. 31-57, 2009.

[53] H. G. Dill, S. Khishigsuren, F. Melcher et al., "Facies-related diagenetic alteration in lacustrine-deltaic red beds of the Paleogene Ergeliin Zoo Formation (Erdene Sum area, S. Gobi, Mongolia)," Sedimentary Geology, vol. 181, no. 1-2, pp. 1-24, 2005.

[54] F. E. Wickman, "The cycle of carbon and the stable carbon isotopes," Geochimica et Cosmochimica Acta, vol. 9, no. 3, pp. 136-153, 1956.

[55] R. G. Pankina, "Origin of $\mathrm{CO}_{2}$ in petroleum gases (from the isotopic composition of carbon)," International Geology Review, vol. 21, no. 5, pp. 535-539, 1979.

[56] S. M. Rogers, "Deposition and diagenesis of mississippian chat reservoirs, North-central Oklahoma," AAPG Bulletin, vol. 85, no. 1, pp. 115-129, 2001.

[57] A. Karim, G. Pe-Piper, and D. J. W. Piper, "Controls on diagenesis of Lower Cretaceous reservoir sandstones in the western Sable Subbasin, offshore Nova Scotia," Sedimentary Geology, vol. 224, no. 1-4, pp. 65-83, 2010.

[58] K. Al-Ramadan, S. Morad, J. N. Proust, and I. Al-Aasm, "Distribution of diagenetic alterations in siliciclastic shoreface 
deposits within a sequence stratigraphic framework: evidence from the Upper Jurassic, Boulonnais, NW France," Journal of Sedimentary Research, vol. 75, no. 5, pp. 943-959, 2005.

[59] K. E. Higgs, H. Zwingmann, A. G. Reyes, and R. H. Funnell, "Diagenesis, porosity evolution, and petroleum emplacement in tight gas reservoirs, Taranaki Basin, New Zealand," Journal of Sedimentary Research, vol. 77, no. 12, pp. 1003-1025, 2007.

[60] A. Khidir and O. Catuneanu, "Predictive diagenetic claymineral distribution in siliciclastic rocks as a tool for identifying sequence boundaries in non-marine successions: the Coalspur Formation, west-central Alberta," Geologos, vol. 15, no. 3-4, pp. 169-180, 2009. 

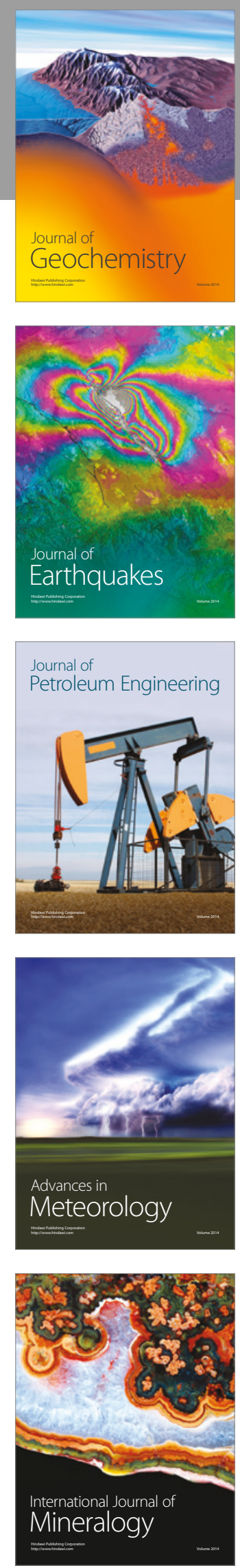
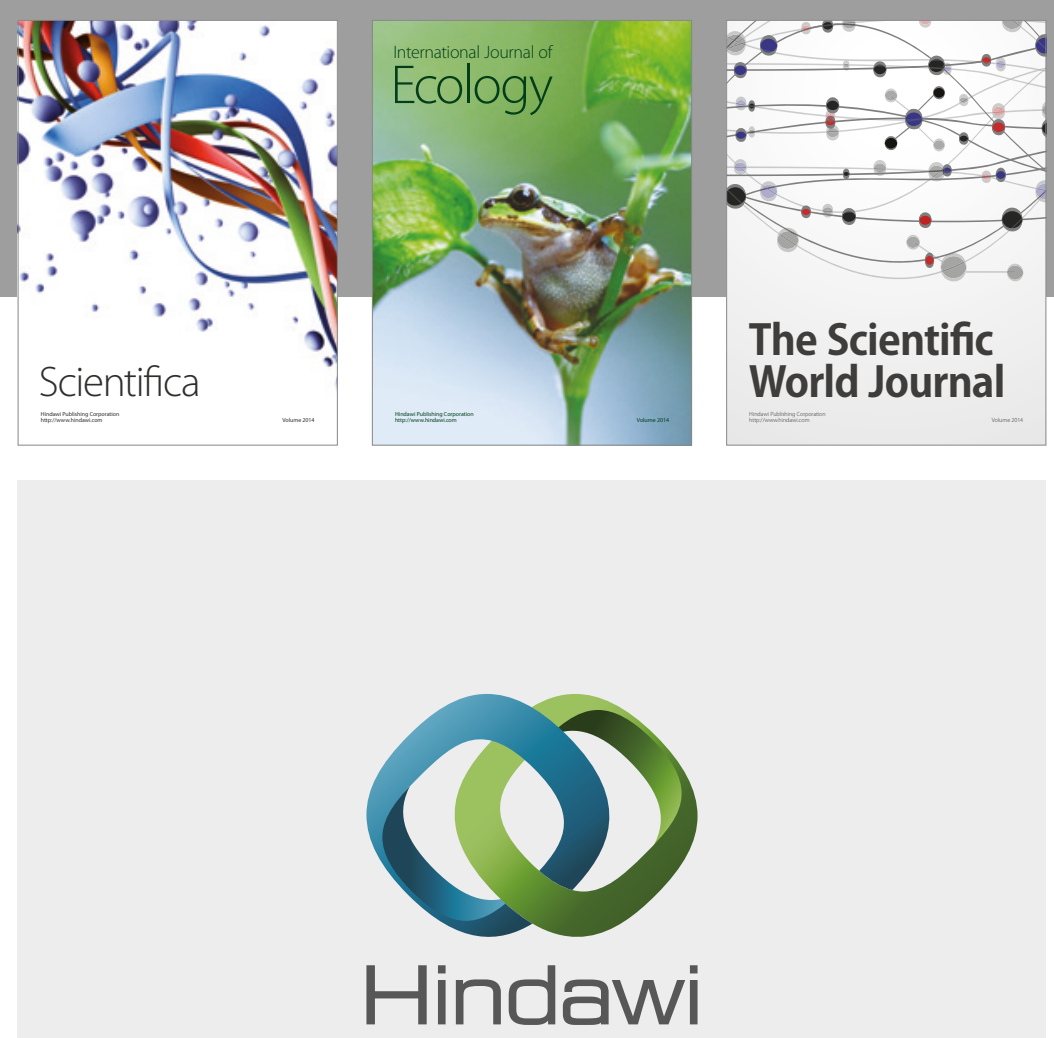

Submit your manuscripts at

https://www.hindawi.com
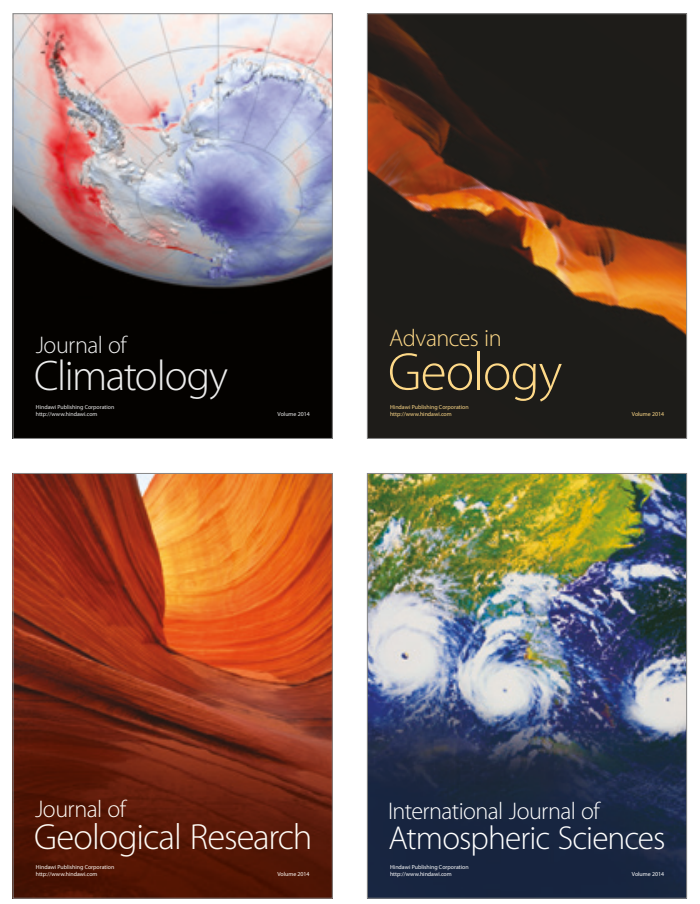

The Scientific

World Journal
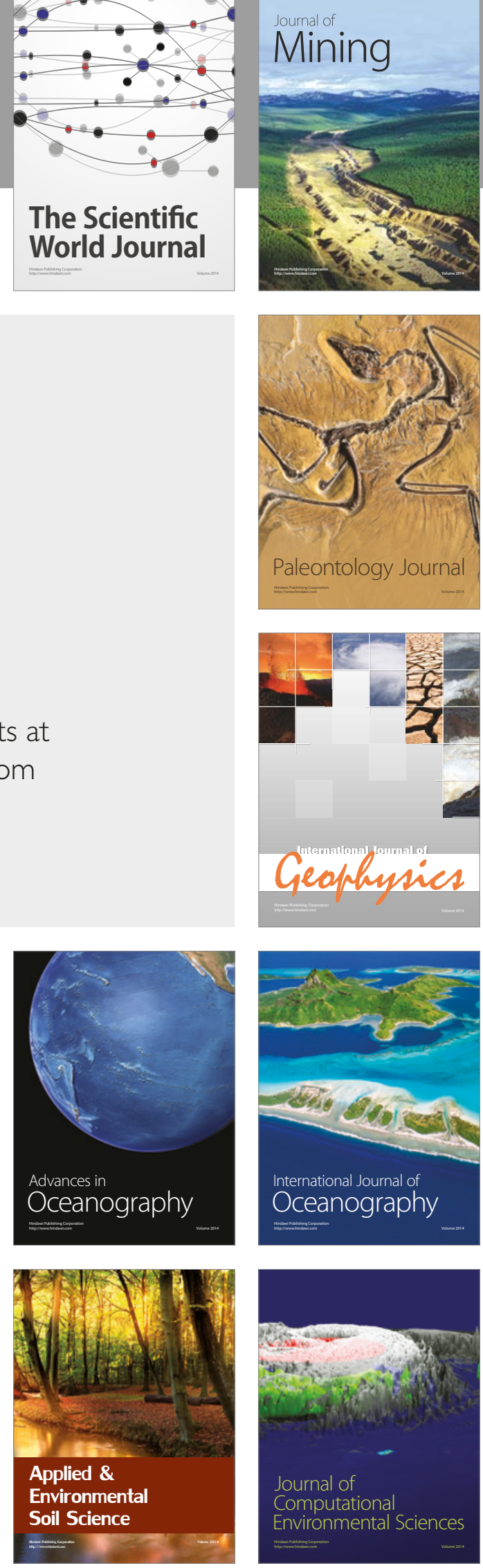